This is an Accepted Manuscript of an article published by Taylor \& Francis in Third

World Quarterly, issue 26(1), 2005; available online: http://www.tandfonline.

com/doi/full/10.1080/0143659042000322928.

\title{
Liberation struggle or terrorism? The politics of naming the LTTE
}

\author{
Suthaharan Nadarajah ${ }^{\mathrm{a}} \&$ Dhananjayan Sriskandarajah ${ }^{\mathrm{b}}$
}

5 August 2004

\section{Introduction}

The protracted conflict in Sri Lanka remains one of the world's most intractable. The ongoing Norwegian-backed effort to resolve peacefully one of South Asia's longest wars is, as the time of writing, bedevilled by fresh acrimony and antagonism between the Sri Lankan state and the Liberation Tigers of Tamil Eelam (LTTE), sometimes referred to as the 'Tamil Tigers.' Since tensions in the Tamil-dominated areas of the island erupted into open confrontation between several armed groups and the state in 1983 in the wake of the fiercest anti-Tamil rioting since independence from Britain, the fighting has grown in intensity and affected most of the Northeast. Inevitably, the origins, nature and character of the conflict are contested by the protagonists and other actors. But the two protagonists' rationale for their actions generally falls within two predominant explanatory frameworks. The LTTE says it is spearheading an armed struggle for political independence for the Tamils as a response to institutionalised racism and violence against the Tamil people by a Sinhala-dominated state. In short, it is waging a 'liberation struggle.' The LTTE describes itself as a 'national liberation movement deeply embedded in [the] people, articulating the wishes and aspirations of the Tamil nation. ${ }^{1}$ On the other hand, describing itself as a democracy, the Sri Lankan state denounces the LTTE's violence campaign as a challenge to its authority, unity and territorial integrity. The state

\footnotetext{
${ }^{\text {a }}$ Department of Politics and International Studies, SOAS University of London

b School of Geography and the Environment, University of Oxford
} 
is 'fighting terrorism.' Thus, the state's military response is rationalised as necessary to 'destroy the terrorists' and 'break the back' of terrorism. ${ }^{2}$

While the narratives presented by the LTTE and the state in support of their respective positions are complex and range across a number of issues, this paper is primarily concerned with the politics of the terrorist label as applied to the LTTE. To be clear, it does not set out to answer the question as to whether the LTTE is a terrorist organisation or not, but instead to demonstrate how the state's characterisation has impacted on the conflict in Sri Lanka. The article begins by pointing out that the terrorist label has been a central feature of Sri Lankan political discourse for several decades, irrespective of the strength of violent challenge to the state. Secondly, we outline how the Sri Lankan state has deployed the label of terrorism to further its strategic aims in the domestic and international spheres. Thirdly, we contend that the ascription of terrorism has not necessarily impeded the LTTE's organic growth in terms of its military capability but has, by denying the organisation international legitimacy, undermined its political project. Fourthly, we outline the contradictions between present international attitudes to terrorism and the conduct of key international actors in regard to the conflict in Sri Lanka. Finally, we argue that in the context of its armed forces' failure - and perhaps inability to defeat the LTTE, the state's sustained rhetoric of terrorism has become a serious impediment in reaching a permanent resolution of the conflict. Beginning with a brief outline of the Sri Lankan conflict, the article then turns to each of these issues in turn.

\section{Context}

In early 2002, a long running but low key Norwegian initiative to bring about a negotiated solution to the conflict in Sri Lanka began in earnest with the establishment of an internationally monitored cease-fire. The truce brought to an end the most intense phase of the conflict - seven years of pitched battles between the LTTE and the Sri Lankan armed forces. The armed struggle for independence launched by the LTTE and other Tamil armed groups in the late 1970s escalated in 1983 following the widespread anti- 
Tamil riots in the capital Colombo and other parts of the island in July that year. Despite three attempts at negotiations - in 1985, 1989-90 and 1994-5 - fighting between the LTTE (which emerged on top from a series of internecine battles amongst the Tamil groups in the late 1980s) and the state's armed forces had gradually escalated in both intensity and scope. An estimated ninety thousand people, mainly civilians, have been killed and a million others internally displaced or made refugees.

Since its inception in 1972 as a small group of fighters, the LTTE had, by the turn of the century, expanded into a substantial military organisation, fielding several thousand fighters in set piece battles with the state's (also expanded) military and backing them with heavy artillery and a large naval force. ${ }^{3}$ By the time the cease-fire came into effect, the LTTE was claiming control of over 70 per cent of the predominantly Tamil areas of the North and East (though not the five main population centres, which remain under government control). The LTTE has built a civil administration structure in the areas it controls, including a police force, a justice system, and humanitarian assistance arm. It operates a taxation system, both in territory under its control and government-held areas, and a customs regime at 'borders' defined by the frontlines. ${ }^{4}$ Since the late 1990s this civil administration has developed to an extent it has been described as a de-facto state. ${ }^{5}$

The LTTE has expanded its political presence since the advent of the peace process. Even before the truce began, Sri Lanka's four largest Tamil political parties forged a coalition with a manifesto of recognising the LTTE as the 'sole representatives' of the Tamil people. ${ }^{6}$ In parliamentary elections held in April 2004, the Tamil National Alliance (TNA), campaigning as self-acknowledged 'proxies' of the LTTE, swept the polls in the Northeast, securing 22 seats. From September 2002 to March 2003, the LTTE engaged in six rounds of high-profile talks with the government. The negotiations were chaired by Norway and held in Thailand (September, October, January), Norway (December), Germany (February) and Japan (March). The LTTE withdrew from the talks in April 2003 protesting the government's failure to implement agreements already reached. 
Efforts to restart negotiations have been unsuccessful, and at the time of writing, although the truce is holding, strains are deepening.

\section{A pivotal device}

Even before the advent of Tamil militancy, the term 'terrorism' had entered Sri Lanka's political discourse in the wake of the brief but bloody insurgency launched by the Marxist Janatha Vimukthi Perumana (JVP) against the state in 1971. Notably, the JVP membership was almost entirely made up of Sinhalese youth - an estimated ten thousand of whom perished in the state's crushing response. Despite occurring on a much smaller scale to the JVP insurgency and involving a handful of political killings and other relatively small acts of sabotage, Tamil militancy in the 1970s was already being described domestically, and in some cases internationally, as 'terrorism.' The introduction of the Prevention of Terrorism Act (PTA) in 1979, formalised the language of terrorism and, as detailed below, conflated terrorism with the Tamil political project in Sri Lankan political discourse. By the time Tamil militants staged the attack on armed forces that led to (and was even cited as a cause of) the anti-Tamil pogrom of July 1983, the discourse of terrorism was well-entrenched. For example, President Jayawardene's call in June that year on Sinhalese to 'do their bit' to fight terrorism was typical of the language used to describe Tamil militancy: 'We are in the throes of increasing terrorist activity in the north... The Tigers are getting bolder and bolder. Hence I appeal to the nation not to allow terrorism to take root in other parts of the country. ${ }^{7}$ At the international level, this characterisation of Tamil militancy as terrorism was quickly adopted by some Western states - in contrast, for example, to India. ${ }^{8}$

How this early language of terrorism developed, and its impact on the conflict, can best be understood by looking at the historical and wider discursive contexts in which it took place. For a start, it is important to note the process by which ethnicity has been essentialised in Sri Lanka, such that major actors within and outside Sri Lanka have come to understand the conflict through a certain framework. The process by which this 
essentialisation has taken place, eloquently described by Ronald Herring, has had wideranging impacts on the politics naming of the LTTE. ${ }^{9}$ Similarly, these politics must be considered in the context of the LTTE and the Sri Lankan state addressing three separate audiences: Tamils, Sinhalese and the international community (including other governments, international non-governmental organisations, and the media). Although somewhat crude, this typology helps explain why the politics of naming has evolved.

When several Tamil armed groups emerged in the late 1970s and early 1980s to mount a violent challenge the Sri Lankan state, they did so in a context of acute ethnic polarisation in the island's politics and a sense of victimisation by the state amongst Tamils. Indeed, the growth of a Tamil political community was conditioned by rising concern about Sinhala dominance in the island's governance in the wake of Ceylon's independence from Britain in 1948. Tensions between Tamils and Sinhalese became serious in 1956 after the election victory of the Sri Lanka Freedom Party (SLFP), the implementation of the 'Sinhala Only' policy and the first ethnic riots. An ethnic fault line at the centre of the island's politics was crystallised: 'Tamils and Sinhalese [became] dangerous shorthand devices for politically complex communities' and the essentialising of ethnicity - 'to speak of Tamils as a whole and Sinhalese as a whole' - fed into the stereotyping strategies of chauvinists. ${ }^{10}$

The growth in Tamil militancy in the late 1970s also took place in the context of growing Tamil agitation for self-determination. Indeed, the call for an independent state of 'Tamil Eelam' was a central plank of the newly formed Tamil United Liberation Front (TULF) that swept the parliamentary elections in the Tamil dominated districts of the North and East in 1977. At this time, armed Tamil groups were arguably marginal in the politics of Tamil independence, which was dominated by the TULF. Apart from being numerically small - which only changed, albeit rapidly, following the anti-Tamil pogrom in 1983 the groups followed, initially at least, in the wake of the TULF in pursing the goal of Tamil Eelam. 
The state's response responses to these two developments - the Tamil call for secession, led by the TULF, and the sporadic violence of the armed groups - are critical to understanding the trajectory of ethnic relations and the conflict in Sri Lanka. The United National Party (UNP) government of President Jayewardene conflated the two issues through an 'incremental reframing of secessionist protest in Jaffna as terrorism' and, in turn, 'terrorism in the late 1970s and early 1980s became conjoined with Tamil ethnicity.' Most importantly, 'Once the political demands of Tamil youth were perceived in terms of terrorist threat, mirror images of ethnic entities hardened. ${ }^{, 11}$

The proscription of the LTTE and other armed Tamil groups in May 1978 and the enactment of the PTA in July 1979 suggest the emphasis placed on the ascription of Tamil militancy as terrorists by the Sri Lankan government. At that time, there was incongruence between the scale of Tamil militancy and the scale of the government's discursive and military response. The LTTE's own 'diary of combat' lists only a handful of small-scale attacks in the years before 1983 and the LTTE was only officially blamed by the state for only one political assassination - in 1974 - in the lead up to the proscription and the PTA. In contrast, the proscription of the JVP, which has staged a far more spectacular insurgency by then, did not take place until July 1983, and even then only after the JVP performed well local and presidential elections.

Shortly after the PTA was passed a substantial military force - made up overwhelmingly of Sinhalese personnel - was dispatched to the North. Ensuing reports of human rights violations were widely publicised by international human rights groups and frequently raised with the government by aid donors, particularly the Nordic countries and Canada. However, simultaneously, 'there was a certain amount of rallying around the state' by international actors and 'despite harsh international criticism, the regime continued to garner critical external support in the aggregate.' Amid the economic hardships of the late 1970s and early 1980s, 'the [subsequent] escalation of the conflict created scapegoats for mass frustration and at least some perception among the Sinhalese majority that 'our government' is besieged by Tamil insurgents and deserves support.' Much of this was in 
the context of the pro-West regime's enthusiasm for liberalisation and donors' 'holistic' approach in using the 'nation-state' as the unit of analysis, thereby masking 'internal differentiation experienced by real people on the ground. ${ }^{12}$

In short, deploying the rhetoric of terrorism had three distinct benefits for the Sri Lankan state: it de-legitimised (Tamil) agitation for political independence (with which terrorism had been conflated) thereby enabling the ‘securitisation' of the issue; it mobilised Sinhala sympathy for the regime and its actions; and, international criticism of rights abuses notwithstanding, did the same abroad. These dynamics were amplified in 1983, a year widely considered a watershed in Sri Lanka’s ethnic relations and conflict.

\section{The road to war}

The consequences of the conflation of ethnicity and violence ('Tamil terrorism') by the state, particularly in the context of long-standing and now serious communal antagonism, were inevitable. As we noted above, whilst Tamils and Sinhalese were politically complex communities, they came to be referred to as monolithic wholes. Crucially, the militants and the state also came to be viewed as genuinely representing Tamils and Sinhalese political interests respectively. In particular, despite political disagreements within each community, the leadership of the other was accepted. The state played a crucial role in this by publicly adopting a partisan role as leaders of the Sinhalese in their conflict with the Tamils. President Jayewardene's declaration, weeks before the events of July 1983, is a typical example:

'I am not worried about the opinion of the Tamil people... now we cannot think of them, not about their lives or their opinion... the more you put pressure in the north, the happier the Sinhala people will be here... Really if I starve the Tamils out, the Sinhala people will be happy.' 13 
Another important response by the state was to prohibit the espousal of separatism. This manifested itself most clearly in an amendment to the Sri Lankan constitution in 1983 that foreclosed a debate on the central Tamil demand and compelled the TULF's MPs to resign their seats. The amendment deemed:

'No person shall, directly or indirectly, in or outside Sri Lanka, support, espouse, promote, finance, encourage or advocate the establishment of a separate state within the territory of Sri Lanka.'

In the wake of the July 1983 pogrom and this criminalisation of Tamil secessionist demands, the ethnic conflict escalated sharply. The Tamil militants' call for armed struggle for political independence struck a chord amongst Tamils. Several Tamil militant groups expanded rapidly, drawing recruits and financial support from the Tamil community, both in the island and from the diaspora. The scale and frequency of guerrilla attacks on security forces rose rapidly, mainly in the Jaffna peninsula but in other parts of the Northeast as well. The conflict has continued since, apart from a few months in 199091 and 1994-5. The guerrilla war of the 1980s gradually changed to one in which both the LTTE and the state controlled different areas of the Northeast and launched full scale military offensives against each other.

These developments, however, have not been translated into changes to the discursive context, which remains one of 'liberation struggle' versus 'terrorism.' Here, it is useful to turn to the three separate audiences (Tamils, Sinhalese and the international community) that the state and the LTTE were addressing. Domestically, the label of terrorism, though prevalent, became relatively meaningless. It was understood by both Tamils and Sinhalese as part of the state's criminalisation of Tamil agitation for political independence/autonomy. As such, neither the Tamil militant groups nor the 'Sinhala' state seriously sought to convince the 'other' community of the legitimacy of their respective causes. Indeed, it was a decade later that the state, amid a new counterinsurgency strategy, altered its rhetoric to differentiate 'LTTE terrorism' from 'Tamil 
terrorism.' Just as the Sinhala perspective saw militant violence as conducted on behalf of and endorsed by the independence-seeking Tamils, Tamils saw violence by the state security forces as conducted on behalf of and endorsed by the domineering Sinhalese.

Meanwhile, press coverage of the July 1983 pogrom and the sudden exodus of refugees to nearby India and Western countries raised the international profile of Sri Lanka's 'ethnic problem' - as did the sharp escalation of the conflict after July 1983. The rhetoric and logic of terrorism therefore became a key part of the international legitimacy of the state and its actions. This, combined with the domestic redundancy of the term, has shaped the discourse of terrorism in Sri Lanka from the outset and to the present. In short, both the state and the LTTE deployed and contested the label in any seriousness only in the context of shaping international opinion.

\section{International centrality}

Sri Lanka’s long running conflict has sometimes been described, erroneously in our view, as 'the forgotten struggle.' The island's location astride the Indian Ocean sea routes and proximity to India, the regional superpower, has always ensured a degree of international attention, not least New Delhi's. India's ill-fated intervention in 1987 to enforce the IndoSri Lanka pact resulted in thousands of casualties. Sri Lanka's 'internal' conflict is affected by international developments in several ways. Firstly, Sri Lanka's economy has failed to fulfil its potential as a consequence of the conflict and international financial assistance is vital to the state's functioning. Moreover, the economy is reliant on foreign markets, both for its export income and for remittances from migrant workers and expatriates. For its part, the LTTE has an extensive fundraising network amongst the Tamil diaspora, made up in large part by refugee and conflict-related flows into countries such as Canada, the United Kingdom (UK), Switzerland, France, Australia and India. ${ }^{14}$ Secondly, the central political issue of the conflict, which both protagonists agree is the demand for political independence, makes the international community important actors in the 'internal' conflict. It is in these contexts that international interpretations of the 
conflict become central to the protagonists' strategic objectives. The legitimacy of the LTTE's armed struggle - and hence the label of 'terrorism' - is at the centre of this interpretive contest.

Here, there are some important parallels to the conflict in Bosnia. As David Campbell demonstrates for that conflict, 'the settled norms of international society were ... complicit and necessary for the conduct of the war itself.' Two predominant views of what the war in Bosnia was about are evident: '[the Serb view] is the tale of a civil war in which antagonism between various groups emerged for a variety of reasons. The [Bosnian government view] is of international conflict, in which aggression from one state threatens another.' 'In their interpretation of the conflict, [the international community] adhered to a limited range of representations. Moreover, they are representations that have had more in common with the Serbian position than that of the Bosnian government.' This had a direct impact on international efforts to resolve the conflict and on the way it was reported on by the international media. Not least, the logic of 'warring factions,' 'ancient hatreds' and 'civil war' and a rejection of the 'genocide' claim precluded international enthusiasm for directly supporting the Bosnian government. Campbell demonstrates that the 'local' narrative which becomes accepted by international actors can be expected to drive their policies. ${ }^{15}$

As such, successfully ascribing or resisting the label of terrorism is thus the most important ideational objective in the international arena. For the LTTE, it is the notion of a civil/ethnic war narrative that can best segue into the arena of national liberation and political independence. For the state, it is the notion of terrorism that paves the way for both strong military action and non-engagement with its opposition's political demands. In the mid-1980s, for example, the LTTE rationalised its armed struggle in the framework of self-determination of the Tamil people: 'Our struggle is for self determination, for the restoration of our sovereignty in our homeland. We are not fighting for a division or separation of a country but rather, we are fighting to uphold the sacred right to live in freedom and dignity. In this sense, we are freedom fighters not terrorists. ${ }^{16}$ Moreover, the 
LTTE, along with other Tamil groups, argued resistance to state terrorism: 'under conditions of national oppression and the intensification of state terrorism and genocide against our people, the demand for a separate state became the only logical expression of the oppressed Tamil people. Our armed struggle is the manifestation of that logical expression. ${ }^{, 17}$ The state also appealed to the internationally accepted principle of stability. As National Security Minister Lalith Athulathmudali argued 'no country in the world has succeeded by being soft on terrorism. ${ }^{18}$

\section{What's in a name?}

A cursory survey of international responses suggests neither narrative has been accepted in its entirety. The LTTE has been proscribed under anti-terrorism legislation by the United States (in 1997), UK (in 2001) and India (in 1991). Other countries, such as Australia and Canada (both in 2002), have proscribed its fundraising activities. The LTTE has not always been proscribed in Sri Lanka: a ban was imposed in 1978 and lifted in 1988 to permit negotiations; then re-imposed in January 1998 and lifted in September 2002, again ahead of negotiations. Yet, despite these proscriptions, the internationally backed Norwegian peace process is based on a parity between the protagonists - not least the tacit acceptance in the cease-fire agreement of two separate controlled areas demarcated by a frontline - at least in so far as the negotiation process is concerned. For its part, the Sri Lankan state is being compelled to negotiate with the LTTE and hence recognise it. Moreover, international pressure is impelling the state towards a domestic anathema - a political solution to the conflict based on autonomy for the Tamil areas, albeit short of independence.

If the objective of the Sri Lankan and international proscriptions of the LTTE were to undermine the organisation's (military, political and administrative structural) growth, they have been demonstrable failures. Evicted from its stronghold of Jaffna in a Sri Lanka Army (SLA) offensive in late 1995, the LTTE retreated to the Vanni jungles and in 19968 was forced to defend itself against a series of further SLA offensives. The imposition of 
the US ban in October 1997 coincided with the largest military operation ever mounted by the SLA. Sri Lanka's 1998 proscription occurred amidst widespread belief the LTTE was on the point of collapse. However, in late 1999, the LTTE launched a series of counteroffensives that not only recaptured the territory it had lost since 1996 but also overran the SLA's largest base complex located at the neck of the Jaffna peninsula. The defeats prompted the state to scramble for international assistance - which proved forthcoming - to prevent Jaffna falling again to the Tigers. Moreover, in the fighting of 2000 and 2001, the LTTE, unveiling a significant new conventional military force, seriously damaged the SLA's offensive capability. In mid-2001, the LTTE launched a major attack on Sri Lanka's sole international airport-cum-airbase in Colombo, destroying several military jets and airliners of the national carrier. The subsequent increases in insurance premiums on air and sea movement, and the decline in tourist arrivals, had a detrimental effect on the Sri Lankan economy, contributing to the first annual contraction since independence.

The military outcomes and, most importantly, the scale of these battles suggest the international and domestic proscriptions have failed to undermine the LTTE's ability to recruit and raise funds. Yet, the timing of Sri Lanka's ban and the US proscription suggest they were less intended to weaken the LTTE - which at the time was considered on the verge of defeat any way - than in undermining its political project, namely Tamil political independence. The US designation of the LTTE as a Foreign Terrorist Organization (FTO) is particularly important in this regard, given the ban is intended to: 'stigmatize and isolate designated terrorist organizations internationally,' 'signal to other governments [US] concern about named organizations' and 'deter donations or contributions to and economic transactions with named organizations. ${ }^{19}$ Given that the LTTE was not known to have a significant fundraising presence in the US and an acceptance amongst US security analysts that the LTTE does not pose a threat to US interests, the FTO designation's political impact assumes much greater significance internationally. ${ }^{20}$ As US Secretary of State Colin Powell put it, '[we] consider terrorism to be unacceptable, regardless of the [underlying] political or ideological purpose.' ${ }^{21}$ 
Part of the explanation for the proscription of the LTTE by the US and other states has to do with the challenge that the LTTE's political project of establishing an independent state rather than, say, the direct threat the LTTE poses to their national interests. No country has recognised the claim for Tamil self-determination. ${ }^{22}$ As Adrian Guelke points out, there is a latent international resistance to the 'universal' principle of national selfdetermination, particularly when it leads to independence. ${ }^{23}$ Guelke also notes the great powers would accept secession 'when it is limited to sub-units of states, with the further conditions that the right is exercised through the ballot box and [that minority rights are protected]. Rejected, at least in principle, will be the carving out of new political entities by the use of force. ${ }^{24}$ Furthermore, while political violence is 'self-legitimizing when applied to autocracies,' the conventional wisdom rules out the legitimacy of political violence in democracies: 'democracies are seen to provide dissenters with peaceful ways to achieve their ends. Political violence is less likely because there is no 'need' for it.' ${ }^{25}$ The US State department, meanwhile, describes Sri Lanka as 'democratic republic with an active multiparty system' - even as it admits 'institutionalized ethnic discrimination against Tamils remains a problem.' ${ }^{26}$

The question as to whether the LTTE is or is not considered a terrorist group by Western governments has not discernibly diminished its support base within the Tamil diaspora. On the contrary, the proscriptions may even have consolidated the resolve of the Tamil diaspora organisations in supporting the Tamil nationalist project and the LTTE. ${ }^{27}$ Certainly the Tamil diaspora has lobbied hard in support of the LTTE, especially in the lead up to the US and UK proscriptions, even going as far as leading a legal challenge against the former. ${ }^{28}$ The LTTE has itself also been manoeuvring diplomatically and politically to shake off, or at least cast doubt on, the terrorist tag. ${ }^{29}$ Meanwhile, sections of the Sinhalese diaspora, supported by the Sri Lankan state, have also been involved in campaigning against the LTTE. ${ }^{30}$

\section{Contradictions}


The LTTE is thus at the centre of several paradoxes in prevailing international norms. Despite increasingly hostile international attitudes to political armed struggles - many of which are now framed by the discourse of terrorism - negotiation, rather than a military solution, is deemed the appropriate response to the LTTE's challenge to the Sri Lankan state. The LTTE has been banned in several countries, but negotiations with the Sri Lankan government brokered by Norway are proceeding on the basis that it represents Tamil political interests. The US and the UK are actively promoting the negotiations between the LTTE and the Sri Lankan state, implicitly recognising the LTTE as the appropriate party to negotiate the terms of a Tamil region's autonomy within Sri Lanka. Their allies like Germany, Japan and Thailand have hosted the talks, whilst simultaneously supporting the 'war on terror' in other arenas. Following the LTTE's declaration in December 2002 that it was prepared to explore federalism as a possible solution to the conflict, LTTE delegations have toured a number of countries, including France, Spain, Switzerland and South Africa to examine constitutional models and governance arrangements. Many important states (such as the UK, China, Germany, Italy and Japan) and international organisations (such as the World Bank, Asian Development Bank and several United Nations agencies) have, since the 2002 cease-fire, established diplomatic contacts with the hitherto ostracised LTTE. Whilst this demonstrates an increasing willingness on the part of these actors to see beyond the terrorist label in the case of the LTTE, even amid reports it continues to develop its military ('terrorist') capability, limits on interactions between the LTTE and international actors remain. The willingness of many actors to interact with the LTTE, even on 'universal' matters of human rights and humanitarian affairs, remains conditional on the Sri Lankan state's approval. Furthermore, international funding for rehabilitation work in LTTE-controlled areas remains controversial, despite guarantees of transparency via international auditing, because some donors are uncomfortable directing funds through a 'non-government' entity. ${ }^{31}$

In the meantime, the labelling of the LTTE as a terrorist organisation can be seen to be impacting on efforts to resolve Sri Lanka's conflict in several ways. On the one hand, 
some argue that it was the inclusion of the LTTE in the US FTO list amid the international 'war on terror' that has compelled the LTTE to enter the peace process. Whilst there is an element of truth in this, the effect of international pressure cannot be overstated. The argument that the LTTE is forced into talks also ignores the considerable benefits that accrue to the LTTE from the peace process, not least its ability to consolidate its gains in the last round of fighting, its much easier access to supporters SLA-controlled areas and its increased exposure to the international community.

On the other hand, the proscriptions undermine the negotiation process in several ways. The availability of 'neutral' venues is limited, with those countries hosting talks unabashedly contradicting the norms of the 'war on terror.' With regards to formulating a new Constitution that settles the political question, the LTTE's access to constitutional knowledge is also restricted by its characterisation as a terrorist organisation: the US has suggested a federal model like its own might be appropriate for Sri Lanka, but LTTE officials seeking to study it cannot visit the US, or for that matter go to Canada. The undertaking of humanitarian activities to deliver the 'peace dividend' to the people of the Northeast - something universally recognised as necessary to build support for the peace process - is problematic because the interactions between donor agencies and the LTTE's civil administration may be seen to constitute 'economic transactions' a terrorist organisation under the foreign proscriptions.

These contradictions in international attitudes and practices raise important questions. If Western states are serious about defeating what they see as terrorism through the use of legal and military force, then the LTTE appears an important exception. If, however, the US-led 'war on terror' actually allows for more nuanced and gradual modes of conflict resolution, as appears to be underway in Sri Lanka, then it begs the question as to whether anything has really changed. Guelke's argument that 'the weaker the credibility of international norms, the more likely that the outcome will be determined by the balance of forces within states and that the international community will be compelled to 
recognise (and thereby legitimise) whatever has been created on the ground - even if violence has played a large role in its determination' comes to the fore here. ${ }^{32}$

But it is within the island of Sri Lanka that the rhetoric of terrorism has truly emerged as a serious impediment to peace. The deliberate conflation of 'terrorism' and the Tamil political project by successive Sri Lankan governments has produced a political culture in which the main (Sinhala) parties routinely vie to adopt more hard-line positions on the ‘ethnic question' - a practice which began as long ago as 1956. As a result, a government's readiness to compromise at the negotiating table can easily result in its electoral defeat - as the United National Front (UNF) administration that signed the cease-fire with the LTTE discovered in the elections of April 2004. The hard-line rhetoric from both sides of the political fence in Colombo, meanwhile, compels the LTTE to adopt an equally intransigent position at the table, not least to maintain its credibility and support base.

\section{Conclusion}

As we have seen, the politics of naming the LTTE has been an important feature in Sri Lanka for several decades, with important discursive and even material impacts. Domestically, these politics should be seen in the context of the essentialisation of ethnic politics and the conflation of the Tamil political project with terrorism. Moreover, the incorporation of the logic of ‘fighting terrorism’ into Sri Lanka’s mainstream politics has, along with the inevitable outcome of elections in a divided population, reduced what ought to be serious debates on the constitutional structure of the country into an emotive and dangerous war of words. In short, using the politics of terrorism, the Sri Lanka state has managed to mask the broader questions at the heart of the conflict. Not only has this framework made the conflict intractable, its continued prominence does not augur well for a permanent political settlement of the conflict. 
Internationally, the LTTE has been designated by foreign states as a terrorist organisation, usually through its inclusion in lists of proscribed organisations in recent years. However, the attitudes of foreign states have more to do with their disapproval of the LTTE's political objective of establishing a separate Tamil state than with the perception that the LTTE represents a direct security threat to their national interests. In recent years, despite official proscription and a growing international 'war on terror', foreign states have shown that they are willing to work with the LTTE in shaping a political solution to the conflict. Taken together, these developments suggest that, while the label of 'terrorism' continues to be applied domestically and internationally to describe the LTTE, the politics of naming have not necessarily impeded the international community's pragmatic approach to conflict resolution in Sri Lanka.

\footnotetext{
${ }^{1}$ Letter from LTTE leader Vellupillai Pirapaharan to Sri Lankan President Chandrika Kumaratunga, 28 March 1995. http://www.tamilnation.org/conflictresolution/tamileelam/cbktalks/950328vptocbk.htm. ${ }^{2}$ W Claiborne, 'Sri Lankan Leader Says Marxists Incited Clashes to Cover Coup', The Washington Post, 8 August 1983, p. A15; W Claiborne, 'Sri Lanka Presses Military Drive on Rebels; Israeli Aid Reported', The Washington Post, 9 August 1984, p. A25

${ }^{3}$ Jane's Sentinel, 'The success of the LTTE in resisting the Sri Lankan forces' 4 September 2000 http://www.janes.com/security/international_security/news/sentinel/sent000904_6_n.shtml,

${ }^{4}$ TamilNet, 'LTTE announces tax relief measures', 14 December 2003 http://www.tamilnet.com/art.html?catid=13\&artid=10684

${ }^{5}$ A J Wilson and J Chandrakanthan, 'The de facto state of Tamil Eelam' in Demanding sacrifice: war and negotiation in Sri Lanka, London, Conciliation Resources, 1998. http://www.c-r.org/accord/sri/accord4/ ${ }^{6}$ TamilNet, 'Tamil parties' alliance formed to support liberation struggle'- TULF', 28 October 2001. http://www.tamilnet.com/art.html?catid=13\&artid=6422

${ }^{7}$ United Press International, 'President warns of terrorism', 6 June 1983.

${ }^{8}$ See comments by British Prime Minister Margaret Thatcher and American President Ronald Reagan in E Silver, 'Tamil terror tactics draw fire from Thatcher', The Guardian (London), 13 April 1985; Visit of President J. R. Jayewardene of Sri Lanka, Public Papers of the Presidents, 20 Weekly Comp. Pres. Doc. 891, 18 June 1984; L L Knutson, 'Reagan Backs Sri Lanka's Anti-Terrorist Drive', Associated Press, 18 June 1984.

${ }^{9}$ R Herring, 'Making Ethnic Conflict' in Carrots, Sticks and Ethnic Conflict, M J Esman and R J Herring (eds), Ann Arbor, University of Michigan, 2001, pp. 140-74.

${ }^{10}$ Herring, 2001, p. 161. Original emphasis.

${ }^{11}$ Herring, 2001, pp.161-2

${ }^{12}$ Herring, 2001, pp.163, 160 and 153

${ }^{13}$ Interview with Graham Ward, Daily Telegraph (London), 18 July 1983.

${ }^{14} \mathrm{D}$ Byman et al, The LTTE and the Tamil Diaspora' in Trends in Outside Support for Insurgent Movements, Santa Monica, RAND Corporation, 2001, pp.41-60. http://www.rand.org/publications/MR/MR1405/

${ }^{15}$ D Campbell, National Deconstruction: Violence, Identity, and Justice in Bosnia, Minneapolis, University of Minnesota Press, 1998.

${ }^{16}$ LTTE leader V. Pirapaharan in an interview to Anita Pratap, Sunday Magazine (India), 11-17 March 1984. Available online at http://www.eelamweb.com/leader/interview/in_1984/
} 
${ }^{17}$ Statement of LTTE and other Tamil groups made at Thimpu, Bhutan in 1985 during peace talks.

${ }^{18}$ W Claiborne, 'Sri Lanka Presses Military Drive on Rebels; Israeli Aid Reported', The Washington Post, 9 August 1984, p. A25.

${ }^{19}$ US State Department, Fact Sheet on Foreign Terrorist Organizations, 30 January 2003.

http://www.state.gov/s/ct/rls/fs/2003/17067.htm

${ }^{20} \mathrm{~K}$ Cagin and S A Daly, The dynamic terrorist threat: an assessment of Group motivations and capabilities in a changing world, Santa Monica, RAND Corporation, 2004.

http://www.rand.org/publications/MR/MR1782/MR1782.pdf

${ }^{21} 10$ September 2002. http://www.state.gov/secretary/rm/2001/4852.htm

${ }^{22}$ The United States and the United Kingdom limit themselves to acknowledging 'legitimate Tamil aspirations.' See comments by US Assistant Secretary of State John Armitage 14 February 2003, (http://www.state.gov/s/d/rm/17752.htm) and UK Foreign Office Minister Peter Hain (TamilNet, 23 November 2000, http://www.tamilnet.com/art.html?catid=13\&rid=2000112301).

${ }^{23}$ A Guelke, The age of terrorism and the international political system, London, I.B. Tauris, 1998, p. 187

${ }^{24}$ Guelke. 1998. p. 187. Emphasis added

${ }^{25}$ D C Rapoport and L Weinberg, The democratic experience and political violence, London, Frank Cass \& Co, 2001, pp. 2-3.

${ }^{26}$ US State Department, Country Reports on Human Rights Practices 2001, 4 March 2002. http://www.state.gov/g/drl/rls/hrrpt/2001/sa/8241.htm

${ }^{27}$ D Sriskandarajah, ‘Tamil diaspora nationalism' in Encyclopedia of Diasporas, New Haven, Yale/Kluwer, 2004.

${ }^{28}$ Humanitarian Law $v$ Reno, US $9^{\text {th }}$ Circuit Court of Appeals, 3 March 2000.

${ }^{29}$ Letter from LTTE to US Court of Appeal Judges, 6 November 1997. http://www.sangam.org/NEWSEXTRA/ltte.htm.

${ }^{30}$ See, for example, the Society for Peace, Unity and Human Rights in Sri Lanka. http://www.spur.asn.au

${ }^{31}$ Transparency International, Press Release, 11 April 2003. http://www.transparency.org/pressreleases_archive/2003/2003.04.11srilanka.html

${ }^{32}$ Guelke, 1998, p. 188 